\title{
Bulk Shielding Facility Quarterly Report April, May, and June of 1976
}
S. S. Hurt, III
E. D. Lance
J. R. Thomas

\section{OAK RIDGE NATIONAL LABORATORY}




\section{DISCLAIMER}

This report was prepared as an account of work sponsored by an agency of the United States Government. Neither the United States Government nor any agency Thereof, nor any of their employees, makes any warranty, express or implied, or assumes any legal liability or responsibility for the accuracy, completeness, or usefulness of any information, apparatus, product, or process disclosed, or represents that its use would not infringe privately owned rights. Reference herein to any specific commercial product, process, or service by trade name, trademark, manufacturer, or otherwise does not necessarily constitute or imply its endorsement, recommendation, or favoring by the United States Government or any agency thereof. The views and opinions of authors expressed herein do not necessarily state or reflect those of the United States Government or any agency thereof. 


\section{DISCLAIMER}

Portions of this document may be illegible in electronic image products. Images are produced from the best available original document. 


\section{Printed in the United States of America. Available trom National Technical Information Service \\ U.S. Department of Commerce 5285 Port Royal Road, Springfield, Virginia 22161 \\ Price: Printed Copy $\$ 4.00$; Microfiche $\$ 3.00$}

This report was prepared as an account of work sponsored by the United States Government. Neither the United States nor the Energy Research and Development Administration/United States Nuclear Regulatory Commission, nor any of their employees, nor any of their contractors, subcontractors, or their employees, makes any warranty, express or implied, or assumes any legal liability or responsibility for the accuracy, completeness or usefulness of any information, apparatus, product or process disclosed, or represents that its use would not infringe privately owned rights. 
Contract No. W-7405-eng-26

OPERATIONS DIVISION

BULK SHIELDING FACILITY QUARTERLY REPORT.

APRIL, MAY, AND JUNE OF 1976

S. S. Hurt, III

E. D. Lance

J. R. Thomas

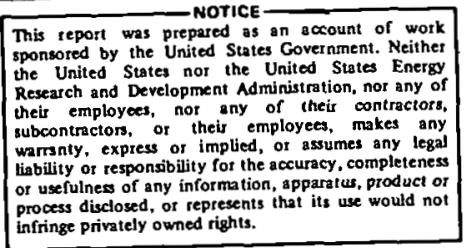

infringe privately owned rights.

Dute Rublished: December 1976

NOTICE This document contains information of a preliminary naturc. It is subject to revision or correction and therefore does not represent a final report.

\author{
UAK KIDGE NATIONAL LABORATORY \\ Oak Ridge, Tennessee 37830 \\ operated by \\ UNION CARBIDE CORPORATION \\ for the \\ ENERGY RESEARCH AND DEVELOPMENT ADMINISTRATION
}




\section{THIS PAGE \\ WAS INTENTIONALLY \\ LEFT BLANK}


CONTENTS

Page

Summary. . . . . . . . . . . . . . . . . . . . . . 1

Bulk Shielding Reactor. . . . . . . . . . . . . . . . . . 1

Operations . . . . . . . . . . . . . . . . . . 1

Shutdowns. . . . . . . . . . . . . . . . 5

Maintenance and Changes . . . . . . . . . . . 6

Status of Ionization Chambers . . . . . . . . . . . 9

Fuel. . . . . . . . . . . . . . . . ... 11

Experiment Facllities Assignment. . . . . . . . . . 12

Demineralizer Performance . . . . . . . . . . . 13

Special Tests. . . . . . . . . . . . . . . . 14

Efficiency Tests. . . . . . . . . . . . . 14

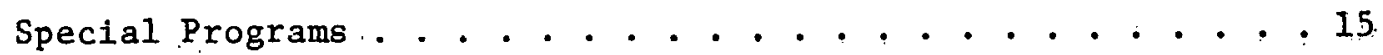

University Nuclear Engineering Department Experiments . 15

Operational Activities . . . . . . . . . . . . 16

Shim Rod Calibrations... . . . . . . . . . . . . 16

Pool Critical Facility. . . . . . . . . . . . . . . . . . 17

Operations . . . . . . . . . . . . . . . . 17

Experiments. . . . . . . . . . . . . . . . . 19

Approach-to-Critical. . . . . . . . . . . . . 19

Regulating Rod Calibration. . . . . . . . . . . . 19;

Statistical Weight. . . . . . . . . . . . I9

Appendix A . . . . . . . . . . . . . . . . . . 20

Distribution. . . . . . . . . . . . . . . . . . 31 


\section{SUMMARY}

The BSR operated at an average power leve1. of $1 ., 7.56 \mathrm{kw}$ for $31.49 \%$ of the time during April, May; and June. Water-quality control in both the reactor primary and secondary cooling systems was satisfactory. The reactor was shut down for $\sim 16$, days to repair a fault $\cdots$ in the fiberglass lining of the pool:

The BSR was operated at low and variable power during this quarter for 79.784 hours as part of the training programs for nuclear engineering students from the University of Tennessee and Mississippi State University.

The PCA was alșo used in the above-mentioned training programs and was-operated on six occasions when the University of Kentucky, Memphis State University, or Missișsippi State University students actively participated in training laboratories.

\section{BULK SHIELDING REACTOR}

Operations

During this quarter, the reactor operated $31.49 \%$ of the time primarily for the irradiation of research experiments. It was operated at low and variable power ( $11.60 \%$ of the operating time) to enable nuclear engineering students from the University of Tennessee and Mississippi State University to perform training labs described elsewhere in this report. Basic operating data.for this period are given in Table 1 .

A new core configuration (Figure 2) is arranged for an experiment consisting of three sections of steel which will be irradiated ot the north and east sides of the reactor core. The east. $\mathrm{D}_{2} \mathrm{O}$ tank has been detached from the reactor structure and placed on a stationary stand in the pool and will be referred to as the stationary $D_{2} 0$ tank. Two additional low weight fuel elements were added to the west side of the core in an attempt to increase the flux for the LTIF. 
Table 1. Basic Operating Data

(April, May and June of 1976)

\begin{tabular}{|c|c|c|c|}
\hline . & $\begin{array}{c}\text { This } \\
\text { Quarter }\end{array}$ & $\begin{array}{l}\text { "Last } \\
\text { Quarter }\end{array}$ & $\begin{array}{l}\text { Year } \\
\text { Tö Date }\end{array}$ \\
\hline Total energy, kwd & 50,301 & 37,412 & 87,713 \\
\hline $\begin{array}{l}\text { Avverage power, } \\
\mathrm{kw} / \text { operating } \mathrm{hr} .\end{array}$ & 1,756 & 1,992 & 1,874 \\
\hline Time operating, \% & $31: 49$ & 20.64 & 26.06 \\
\hline Reactor availability, \% & 60.60 & $\therefore 43.83$ & $\because 52.22$ \\
\hline $\begin{array}{l}\text { Reactor water radioactivity } \\
\text { counts } \mathrm{min}^{-1} \mathrm{ml}^{-1} \text { (av) }\end{array}$ & 1,349 & 2,229 & 1,789 \\
\hline $\begin{array}{l}\text { Reactor water resistivity, } \\
\text { ohm-cm (av) }\end{array}$ & $1,109,000$ & 946,000 & $1,027,500$ \\
\hline $\begin{array}{l}\text { Standard fuel elements } \\
\text { depleted }\end{array}$ & 0 & 0 & 0 \\
\hline $\begin{array}{l}\text { Control fuel elements } \\
\text { depleted }\end{array}$ & 0 & 0 & 0 \\
\hline Research samples & 50 & 36 & 86 \\
\hline
\end{tabular}

Core loading 30 (Figure 1) was replaced by core loading 31 (Figure 2) on June 21 ; 1976, to provide adequate excess reactivity for versatile operation. 'l'he initial operating mass $\left(4226 \mathrm{~g}^{235} \mathrm{U}\right)$ of core loading 30 had been reduced to $4122 \mathrm{~g}$ due to burnup, thereby reducing the excess reactivity from $5.30 \% \Delta \mathrm{k} / \mathrm{k}$ to $\sim 3.66 \% \Delta \mathrm{k} / \mathrm{k}$ ( $\sim 1.11 \%$ excess reactivity above xenon equilibrium).

Lore loading 31 was accomplished by adding two partially depleted BSFserles fuel elements and three new. MTR-series fuel elements. Core loating 31 had an initial operating mass of $4995 \mathrm{~g}$ which provided an excess reactivity of $5.49 \% \Delta \mathrm{k} / \mathrm{k}(2.94 \%, \Delta \mathrm{k} / \mathrm{k}$ excese rcactivity abuve xenon equilibrium). At the end of the quarter, the excess reactivity was $\sim 5.38 \% \Delta \mathrm{k} / \mathrm{k}$ ( $\sim 2.83 \% \Delta \mathrm{k} / \mathrm{k}$ excess reactivity above xenon equilibrium)。 


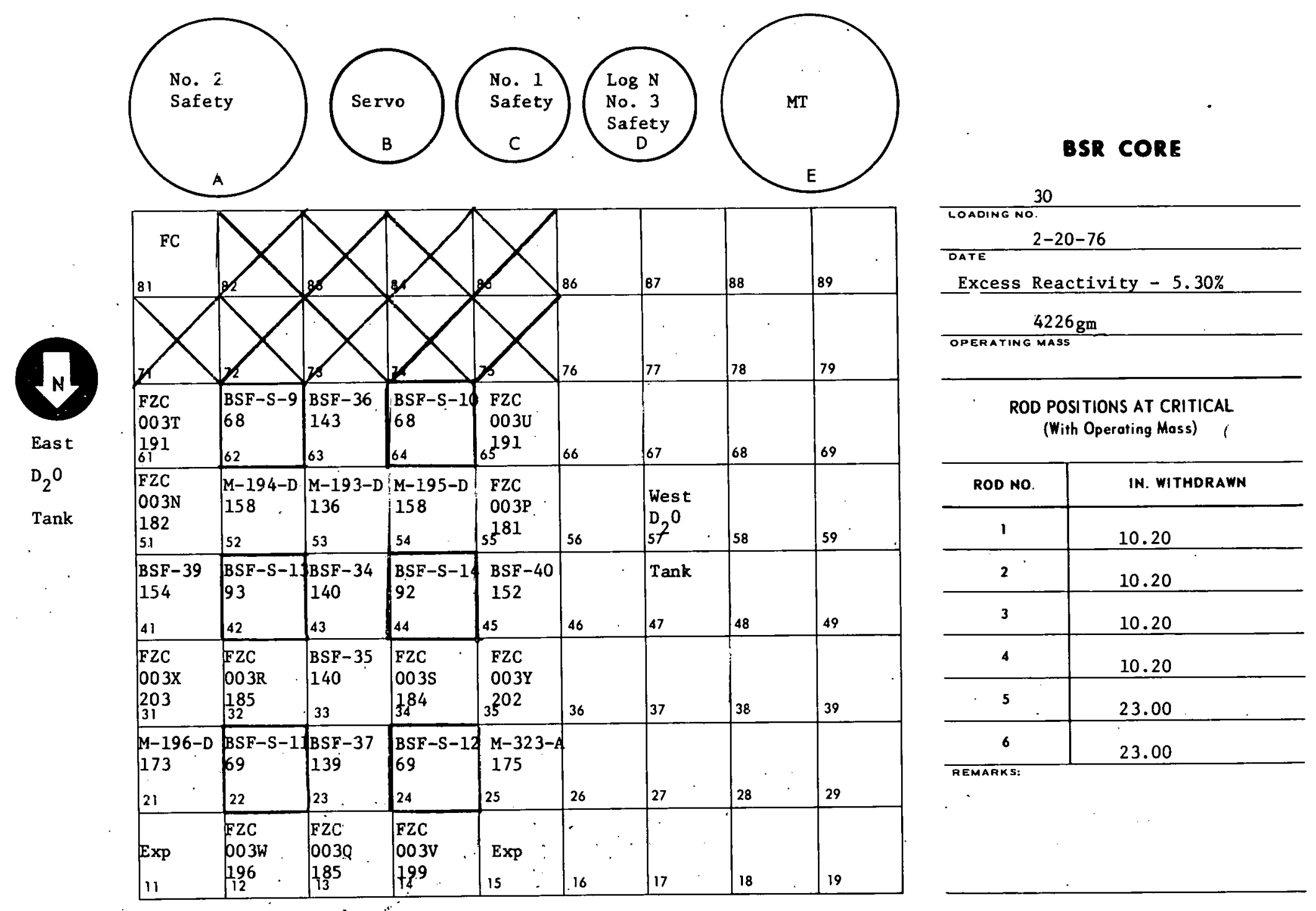

Figure 1. Core Loading 30 - BSR. 


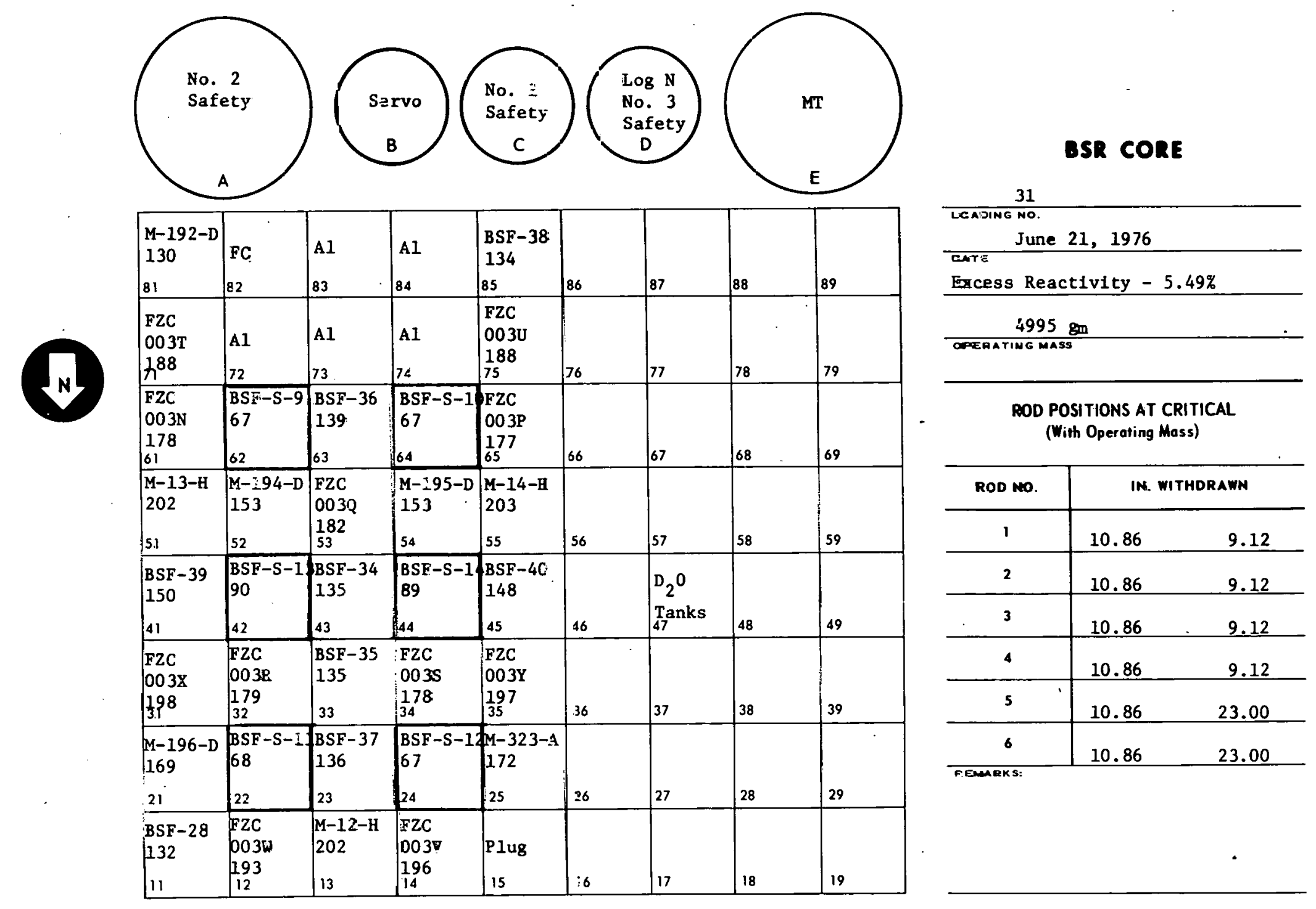

Zigure 2. Core Loading 31 - BSR. 
Shutdowns

There were no unscheduled shutdowns during the quarter. Table 2 gives an analysis of the scheduled shutdowns.

Table 2. Analysis of Shutdowns

\begin{tabular}{|c|c|c|c|}
\hline Description of & atdown & Number. & Downtime. (hrs ) \\
\hline \multicolumn{4}{|c|}{ Scheduled } \\
\hline \multicolumn{4}{|l|}{ Experimenters: } \\
\hline \multicolumn{2}{|l|}{ No request to operate } & 10 & 622.867 \\
\hline \multicolumn{2}{|c|}{ Repositioning of the reactor } & 1 & 0.500 \\
\hline \multicolumn{2}{|c|}{$\begin{array}{l}\text { Experiment insertion, removal, or } \\
\text { data taking }\end{array}$} & 12 & 12.534 \\
\hline \multicolumn{4}{|l|}{ Reactor Operations: } \\
\hline \multicolumn{2}{|l|}{ Special } & 1 & 25.883 \\
\hline \multicolumn{2}{|c|}{ University experiment preparation } & 2 & 6.250 \\
\hline \multicolumn{2}{|c|}{ BSR pool repair \& reassembling reactor } & 1 & 680.000 \\
\hline \multicolumn{2}{|l|}{ Refueling critical runs } & 14 & 3.000 \\
\hline \multicolumn{2}{|l|}{ Quarter1y } & 1 & 111.250 \\
\hline \multicolumn{2}{|l|}{ Shim rod calibrations } & 1 & 33.250 \\
\hline \multicolumn{2}{|l|}{ Subtotal } & 43 & $1,439.534$ \\
\hline \multicolumn{4}{|c|}{ Uns cheduled } \\
\hline \multicolumn{2}{|l|}{ Experimenters: } & 0 & 0 \\
\hline \multicolumn{2}{|l|}{ Reactor Operations: } & .0 & $\underline{0}$ \\
\hline \multicolumn{2}{|l|}{ Subtontal } & 0 & $\underline{0}$ \\
\hline \multicolumn{2}{|l|}{ Total } & 43 & $1,439.534$ \\
\hline
\end{tabular}

Maintenance and Changes

Maintenance or changes on the instrumentation and mechanical components in the complex are listed in Tables 3, 4, 5, and 6 . Table 7 presents the status of the Ionization and fission chambers. 
Table 3. Maintenance and Changes, Instrumentation and Controls

\begin{tabular}{|c|c|c|c|}
\hline Date & Component & Trouble or Change & Reason or Maintenance \\
\hline $4-7-76$ & Log $N$ channel & Erratic readout & Replaced the Log $N$ amplifier. \\
\hline $4-22-76$ & $\begin{array}{l}\text { No. } 1 \text { rod drive Fosition } \\
\text { indicator }\end{array}$ & $\begin{array}{l}\text { The clock-face readout } \\
\text { device was replaced with } \\
\text { a digital position read- } \\
\text { out. }\end{array}$ & $\begin{array}{l}\text { The new unit was installed } \\
\text { for test and evaluation of } \\
\text { the new type of rod drive } \\
\text { position indicator. }\end{array}$ \\
\hline $\begin{array}{l}4-22-76 \\
\text { througt: } \\
4-26-76\end{array}$ & No. 2 TV camera & Poor picture reception. & $\begin{array}{l}\text { The Vidicon tube was replaced } \\
\text { to correct the trouble. }\end{array}$ \\
\hline $4-30-76$ & Building evacuation system & $\begin{array}{l}\text { Failure of the Magenta } \\
\text { lights }\end{array}$ & $\begin{array}{l}\text { A faulty socket for the } \\
\text { Manual Evaucate Module was } \\
\text { repaired to correct the } \\
\text { trouble. }\end{array}$ \\
\hline $5-5-76$ & $\log \mathbb{N}$ channe1 & Erratic readout & $\begin{array}{l}\text { The } \log N \text { amplifier was } \\
\text { replaced. }\end{array}$ \\
\hline $\begin{array}{l}5-19-76 \\
\text { through } \\
5-21-76\end{array}$ & Instrumentation & Routine & Quarterly checks. \\
\hline $5-19-76$ & Counting rate channel & Poor response & $\begin{array}{l}\text { Replaced the balance motor in } \\
\text { the count rate recorder and } \\
\text { the Zener power supply in } \\
\text { the count rate period } \\
\text { recorder. }\end{array}$ \\
\hline $5-20-76$ & No. 1 safety channel & Poor response & $\begin{array}{l}\text { Replaced the balance motor in } \\
\text { the Servo recorder. }\end{array}$ \\
\hline
\end{tabular}


Table 3. (Continued)

\begin{tabular}{cccc}
\hline Date & Cemponent & Trouble or Change & Reason or Maintenance \\
\hline $5-20-76$ & Servo channe1 & Poor response & $\begin{array}{c}\text { Replaced the balance motor in } \\
\text { the servo recorder. }\end{array}$ \\
$5-20-76$ & Public Address System & Amplifier failure & $\begin{array}{c}\text { The amplifier electron tubes } \\
\text { were replaced. }\end{array}$ \\
$6-25-76$ & Servo channel. & $\begin{array}{c}\text { Insensitive braking action... } \\
\text { of the servo motor }\end{array}$ & $\begin{array}{l}\text { A new rectifier was installed } \\
\text { in the servo demand motor } \\
\text { circuit. }\end{array}$
\end{tabular}


Table 4. Maintenance and Changes, Mechanical System

\begin{tabular}{|c|c|c|c|}
\hline Date & ; Çomponent & Trouble or. Change & Reason or Maintenance \\
\hline $5-12-76$ & $\begin{array}{l}\text { Reactor seconciary tower } \\
\text { north far }\end{array}$ & Coupling slipping & $\begin{array}{l}\text { Replaced } 61 / .2 \text { lbs. of S. S. } \\
\text { shot in the Dodge Flexi- } \\
\text { dyne coupling. }\end{array}$ \\
\hline $6-16-76$ & $\begin{array}{l}\text { Shim-rad drive assemblies } \\
\text { Nos. } 1 \text { through } 6\end{array}$ & R.outine inspection & $\begin{array}{l}\text { The drive assemblies were } \\
\text { inspected, the magnets and } \\
\text { clutch switches :cleaned, } \\
\text { the drive tubes brushed } \\
\text { and flushed and the drive } \\
\text { assemblies reinstalled. }\end{array}$ \\
\hline
\end{tabular}

Table 5. Maintenance and Changes, Process Syszem

\begin{tabular}{cccc}
\hline Date & Component & Trouble or Change & Reason or Maintenance \\
\hline $\begin{array}{l}6-28-76 \\
\text { and }\end{array}$ & Secondary pt.system & Erratic readout & $\begin{array}{c}\text { The fluid in the reference } \\
\text { pH probes was changed and } \\
\text { the measuring pH probes } \\
\text { were replaced. }\end{array}$ \\
\hline
\end{tabular}

Taj̈le.6. Maintenance and Changes, . BSR.Services

\begin{tabular}{clll}
\hline Date & Componert & Trouble or Change & Reason or. Maintenance \\
\hline $5-27-76$ & Air conditicning pump & Failure of motor & $\begin{array}{c}\text { Replaced the motor starter } \\
\text { coil. }\end{array}$ \\
\hline
\end{tabular}


Table 7. Status of Ionization Chambers

\begin{tabular}{|c|c|c|c|c|}
\hline $\begin{array}{c}\text { Chamber } \\
\text { Serial No. }\end{array}$ & Location & $\begin{array}{l}\text { Date Present } \\
\text { Service Started. }\end{array}$ & $\begin{array}{l}\text { Previous } \\
\text { Service }\end{array}$ & Remarks \\
\hline \multicolumn{5}{|c|}{ Chambers in Service } \\
\hline $\mathrm{CTC}-3(\mathrm{~J}-118)$ & $\begin{array}{l}\text { Position A, } \\
\text { No. } 2 \text { safety }\end{array}$ & $10-8-69$ & LITR & $\begin{array}{l}\text { The chamber was modified for } \\
\text { underwater serwice in } 1969 .\end{array}$ \\
\hline PCP-III-106, SN-72-1 & $\begin{array}{l}\text { Position } B \\
\text { servo }\end{array}$ & $5-12-75$ & None & $\begin{array}{l}\text { This new chamber was installed } \\
\text { in the BSR in May, } 1975 .\end{array}$ \\
\hline CTC-4 (C-771) & $\begin{array}{l}\text { Position } \mathrm{C} \\
\quad \text { No. } 1 \text { safety }\end{array}$ & $12-1-69$ & LITR & $\begin{array}{l}\text { The chamber was modified for } \\
\text { underwater service in } 1969 .\end{array}$ \\
\hline PCP-III-106A, SN-72-2 & $\begin{array}{l}\text { Position : D, } \\
\text { log-N and No. } \\
\text { 3 saEety }\end{array}$ & $11-13-73$ & None & $\begin{array}{l}\text { This new dual chamber was } \\
\text { installed in the BSR in } \\
\text { November, 1973. }\end{array}$ \\
\hline \multirow[t]{2}{*}{$\Xi-1045$} & $\begin{array}{l}\text { CP-81, fission } \\
\text { chamber }\end{array}$ & $10-1-69$ & PCA & $\begin{array}{l}\text { This fission chamber assembly } \\
\text { was tranferred to the BSR } \\
\text { from the PCA in October, } \\
1969 \text {. }\end{array}$ \\
\hline & : & Chambers Not In Ser & & \\
\hline $\begin{array}{l}\text { FCP (old type, no } \\
\text { serial number) }\end{array}$ & $\begin{array}{r}\text { Warehouse } \\
\text { storage }\end{array}$ & & BSR & $\begin{array}{l}\text { This chamber is of the old. } \\
\text { type and will be repaired } \\
\text { if needed. }\end{array}$ \\
\hline $\begin{array}{c}\text { CIC. (No. 62) } \\
\text {. }\end{array}$ & BSR storage & $:$ & BSR & $\begin{array}{l}\text { This chamber is reserved for } \\
\text { the PCA but can be used in } \\
\text { an emergency for the BSR. }\end{array}$ \\
\hline
\end{tabular}


Table 7 (continued)

\begin{tabular}{|c|c|c|c|c|c|}
\hline $\begin{array}{l}\text { Chamber } \\
\text { Serial No. }\end{array}$ & Location .... & & $\begin{array}{l}\text { Date Present } \\
\text { ervice Started. }\end{array}$ & $\begin{array}{l}\text { Previous } \\
\text { Service }\end{array}$ & Remarks \\
\hline CIC (No. 63) & BSR storage & & & BSR & $\begin{array}{l}\text { This chamber is reserved for } \\
\text { the PCA but can be used in } \\
\text { an emergency for the } B \text { BSR.. }\end{array}$ \\
\hline PCP (Q975), No. 2) & BSR Storage & & & BSR & $\begin{array}{l}\text { This chamber is reserved for } \\
\text { the PCA but can be used in } \\
\text { an emergency for the BSR. }\end{array}$ \\
\hline $\begin{array}{l}\text { PCP-III-106, } \\
\text { SN-66-1 }\end{array}$ & ESR storage & & & BSR & $\begin{array}{l}\text { Used as No. } 2 \text { safety and servo. } \\
\text { Safety section failed in } \\
\text { June, } 1969 \text {, servo section } \\
\text { failed in May, } 1975 \text {. }\end{array}$ \\
\hline $\begin{array}{l}\text { PCP-III-106, } \\
\text { SN-66-3 }\end{array}$ & ORR bean tube & storage & & $\begin{array}{l}\text { BSR and } \\
\text { ORR : }\end{array}$ & $\begin{array}{l}\text { Used BSR and ORR } 1967 \text { through } \\
1973 \text {. Last removed } \\
\text { November, } 1973 \text {. }\end{array}$ \\
\hline $\begin{array}{l}\text { PCP-III-106, } \\
\text { SN-66-4 }\end{array}$ & $\begin{array}{l}\text { ORR instrument } \\
\text { shop }\end{array}$ & . & & BSR & $\begin{array}{l}\text { Used in the BSR from } 1968 \text { to } \\
\text { January, 1973. Repaired } \\
\text { 1969. }\end{array}$ \\
\hline
\end{tabular}


Fue1.

Changes in the fuel inventory are reflected in Table 8.

Table 8. Fuel and Shim Rod S.tatus

\begin{tabular}{|c|c|c|c|}
\hline & $\begin{array}{l}\text { This } \\
\text { Quarter..... }\end{array}$ & $\begin{array}{l}\text { Last } \\
\text { Quarter }\end{array}$ & $\begin{array}{l}\text { Year } \\
\text { To. Date }\end{array}$ \\
\hline Fuel elements depleted & 0 & 0 & 0 \\
\hline Control-rod fuel elements depleted & 0 & 0 & 0 \\
\hline New fuel elements placed in service & 3 . & 2 & 5 \\
\hline $\begin{array}{l}\text { New control-rod fuel elements placed } \\
\text { in service }\end{array}$ & 0 & 0 & 0 \\
\hline New fuel elements available for use & 6 & 9 & 6 \\
\hline $\begin{array}{l}\text { New control-rod fuel elements } \\
\text { available for use }\end{array}$ & 6 & 6 & 6 \\
\hline $\begin{array}{l}\text { Partially depleted fuel elements } \\
\text { available for use }\end{array}$ & 2 & 4 & 2 \\
\hline New shim rods placed in service & 0 & 0 & 0 \\
\hline Boron stainless steël shim rods in use & 6 & 6 & 6 \\
\hline $\begin{array}{l}\text { Boron stainless steel shim rods } \\
\text { available for use }\end{array}$ & 2 & 2 & 2 \\
\hline
\end{tabular}


Experiment Facilities Assignment

Facility assignments are listed in Table 9. The tubes of the east $\mathrm{D}_{2} 0$ tank are not permanently assigned; they are used by various Laboratory personnel for short-term sample irradiations.

Table 9. Facilities Assignment

\begin{tabular}{|c|c|c|}
\hline Facility & Loration & $\begin{array}{l}\text { Division } \\
\text { or Sponsor. }\end{array}$ \\
\hline Liquid helium cryosrat & $\begin{array}{l}\text { Southwest corner of pool } \\
\text { using west } D_{2} 0 \text { tank }\end{array}$ & Solid State \\
\hline Liquid nitrogen cyrostat & On instrument bridge & Solid State \\
\hline Ambient temperature facility & North face of core & Solid State \\
\hline Front-face tube & North face of core & Solid State \\
\hline Fast-neutron tube & Core position 15 & Solid State \\
\hline Water-cooled tube & Core position 11 & Solid State \\
\hline $\begin{array}{l}\text { Dry thermal-neutron tubes* } \\
(\mathrm{N}-4 \text { and } \mathrm{s}-3)\end{array}$ & Stationary $\mathrm{D}_{2} 0$. tank & Operations \\
\hline $\begin{array}{l}\text { Dry thermal-neutron tubes* } \\
\text { (east, center, southwest, } \\
\text { and northwest) }\end{array}$ & Stationary $\mathrm{D}_{2} \mathrm{O}$ tank & Operations \\
\hline
\end{tabular}

Demineralizer. Performance.

Table 10 gives detailed information on the condition of the primary water system for the preceding year and pertinent data ou. Lhe pcrformance. of the bypass demineralizer. 
Table 10. Demineralizer Performance Data

\begin{tabular}{|c|c|c|c|c|c|c|c|c|c|}
\hline \multirow{2}{*}{$\begin{array}{l}\text { Run } \\
\text { No. }\end{array}$} & \multirow{2}{*}{$\begin{array}{c}\text { Initiation } \\
\text { Date } \\
\end{array}$} & \multirow{2}{*}{$\begin{array}{c}\text { Termination } \\
\text { Date. }\end{array}$} & \multirow{2}{*}{$\begin{array}{l}\text { Throughput } \\
\text { (gal) }\end{array}$} & \multirow{2}{*}{\multicolumn{2}{|c|}{ 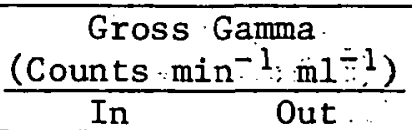 }} & \multicolumn{2}{|c|}{$\mathrm{pH}$} & \multicolumn{2}{|c|}{$\begin{array}{l}\text { Specific Resistance } \\
(\mathrm{ohm}-\mathrm{cm})\end{array}$} \\
\hline & & & & & & In & Out & In & Out \\
\hline 33 & $1-4-73$ & $3-5-73$ & $1,614,000$ & 1,280 & 115 & 5.7 & 5.8 & $1,008,000$ & $1,430,000$ \\
\hline 34 & $3-6-73$ & $4 \div 30 \div 73$. & $1,393,200$ & 1,848 & 181 & 5.7 & 5.7 & 873,000 & $1,363,000$ \\
\hline 35 & $5-2-73$ & $7-2-73$ & $2,060,000$ & 2,072 & 120 & 5.8 & 5.8 & 896,000 & $1,209,000$ \\
\hline 36 & $7-3-73$ & $9-4-73$ & $1,900,000$ & 1,672 & 116 & 5.8 & 5.8 & 792,000 & $1,270,000$ \\
\hline 37 & $9 \div 4-73$ & $11-12-73$ & $1,300,000$ & 2,021 & 107 & 5.9 & 6.0 & 682,000 & $1,144,000$ \\
\hline 38 & $11-14-73$ & $1-7-74$ & $1,692,000$ & 1,353 & 98 & 5.7 & 5.7 & 738,000 & $1 ; 102,000$ \\
\hline 39 & $1 \div 9-74$ & $3-13-74$ & $1,320,000$ & 1,931 & 101 & 6.2 & 6.0 & 666,000 & 908,000 \\
\hline *40 & $3-15-74$ & $7-30-74$ & $1,400,000$ & 9 & 0. & 6.2 & 6.0 & 364,000 & $1,132,000$ \\
\hline 41 & $8-16-74$ & $12-4-74$ & $1,500,000$ & 2,316 & 385 & 5.8 & 5.8 & 630,000 & 895,000 \\
\hline$* * 42$ & $12-17-74$ & $4-15-75$ & $3,850,000$ & 2,116 & 119 & 5.8 & 6.0 & $1,018,000$ & $1,611,000$ \\
\hline 43 & $4-16-75$ & $7-7-75$ & $2,550,000$ & 2,712 & 174 & 5.7 & 5.8 & 937,000 & $1,823,000$ \\
\hline 44 & $7-10-75$ & $11-5-75$ & $2,750,000$ & 2,528 & 144 & 5.7 & 5.9 & 968,000 & $1,428,000$ \\
\hline 45 & $11-5-75$ & $4-29-76$ & $2,325,000$ & 2,146 & 154 & 5.3 & 5.5 & 902,000 & $1 ; 593,000$ \\
\hline$\dot{4} 6$ & $4-30-76$ & In Service & $1,000,000$ & 1,399 & 100 & 5.5 & 5.7 & $1,109,000$ & $2,030,000$ \\
\hline
\end{tabular}

*The reactor was shut down during the entire run.

* ${ }^{*}$ New resin in the demineralizer columns. 
SPECIAL TESTS

Efficiency Tests.

Tests were performed by Inspection Engineering on the cell ventilation filters. Details are given in Table 11.

Table 11. Efficiency Tests Results, Filters

\begin{tabular}{lllc}
\hline Date & \multicolumn{1}{c}{ Uuit } & Type Test & Efficiency (\%) \\
\hline $4-1-76$ & North Bank & Methyl Iodide & 83.73 \\
$4-1-76$ & Center Bank & Methyl Iodide & 71.00 \\
$4-1-76$ & South Bank & Methyl Iodide & 27.10 \\
$6-18-76$ & North Bank & DOP & 99.985 \\
$6-18-76$ & Center Bank & DOP & 99.995 \\
$6-18-76$ & South Bank & DOP & 99.993 \\
\hline
\end{tabular}


The University Nuclear Engineering Department Experiments.

The BSR was used for: training labs for university nuclear engineering students on seven occasions as described below.

A'ttenuation Experiment:- The reactor was operated at variable power levels (on April 31 and.14, 19.76). by the Operations Division staff while the University of Tennessee students, under the auspices of the Operations Division training supervisor, performed a neutron and gamma attenuation experiment. Basically, the experiment was an exercise in measuring neutron and gamma levels from an operating nuclear reactor as a function of distance through light-water medium.

Xenon Buildup and Decay Experiment - On April 2 and 3, 1976, and also on May 7; 8 and 9, 1976, following operation at $2 \mathrm{Mw}$ to achieve xenon equilibrium, the power level of the BSR was reduced to $4 \mathrm{kw}$ to begin an experiment for students from Mississippi State University and the University of Tennessee to study the buildup and decay of xenon in the BSR core. The students performed all activities associated with the experiment under the direct supervision of an Operations pivision supervisor. The experiment, performed on a $24-\mathrm{hr} /$ day schedule until completion, was an exercise in: (1) maintaining the reactor critical at $4 \mathrm{kw}$, (2) determining the reactivity worth of a,shim rod under varying concentrations of xenon, and (3) determining the reactivity worth of xenon in the core as a function of time. 
Operational Activities

\begin{tabular}{|c|c|}
\hline Date & Remarks \\
\hline $5-20-76$ & $\begin{array}{l}\text { The emergency electrical power quarterly test was } \\
\text { completed with satisfactory results. The test was } \\
\text { performed by turning the emergency power transfer } \\
\text { swit'ch" (circuit } 18 \text { in electrical power panel". DP-1) } \\
\text { to "OFF", thereby starting the oRR diesel generator } \\
\text { which supplied electrical. power to designated cir-:" } \\
\text { cuits in the control and pon l rooms. }\end{array}$ \\
\hline $5 \quad 27-76$ & $\begin{array}{l}\text { The containment sysiem quarterily functinnal checks were } \\
\text { performed with satisfactuly iesulto. }\end{array}$ \\
\hline
\end{tabular}

Shim-Rod Calibrations.

The BSR shim rods were calibrated after core loading 31 had been established. The results are shown in Appendix A. The total worth of all six rods was $10.97 \% \Delta \mathrm{k} / \mathrm{k}$. The operating limit requiremenl that the reactor be operated with the ganged rods (all six) withdrawn at least $50 \%$ of their worth thus requires that the rods be $\geq 10.70 \mathrm{in}$. withdrawn when the reactor becomes critical for powar operation, With rods 5 and 6 at 23 in. withdrawn, rods $1,2,3$, and 4 can be withdrawn lu 9.00 in. to comply with the same operating limit. Appendix A alsu shows the comparison of rod worths for October, 1971, January; 1972, September, 1974, and June, 1975 . 
POOL CRITICAL ASSEMBLY

Operations $\because \because$ :

The PCA was used 62.0 hours as an experiment facility for the benefit of nuclear engineering students from the University of Kentucky, Mississippi State University and Memphis State University. Operational activities in preparing the facility for use included a checkout of the reactor control instrumentation and preparation of the required loadings. The operational activities are listed in Table 12. (Usage of Pool Critical Facility). The PCA maintenance is listed in Table 13.

Table 12. Usage of Pool Critical Facility

\begin{tabular}{|c|c|c|c|}
\hline Date & Operational Activity & Purpose': & $\begin{array}{l}\text { Hours } \\
\text { Used }\end{array}$ \\
\hline $4-1-76$ & $\begin{array}{l}\text { Established core No. } 77 \text { to } \\
\text { permit calibration of the } \\
\text { regulating rod and the } \\
\text { performance of the } \\
\text { importance function } \\
\text { experiment. }\end{array}$ & $\begin{array}{l}\text { Training lab för the } \\
\text { Mississippi State } \\
\text { University nuclear } \\
\text { engineering students. }\end{array}$ & 7.4 \\
\hline $4 \div-5-76$ & $\begin{array}{l}\text { Established core No. } 181 \text { to } \\
\text { obtain a critical mass } \\
\text { following the standard } \\
\text { approach-to-critical } \\
\text { procedure. Established } \\
\text { core No. } 182 \text { to permit } \\
\text { calibration of the } \\
\text { regulating rod. }\end{array}$ & $\begin{array}{l}\text { Training lab for the } \\
\text { University of Kentucky } \\
\text { nuclear engineering } \\
\text { students. }\end{array}$ & 13.1 \\
\hline $4-6-76$ & $\begin{array}{l}\text { Eetablished cure No. } 183 \text { to } \\
\text { obtain a critical mass } \\
\text { following the standard } \\
\text { approach-to-critical } \\
\text { procedure. Established } \\
\text { core No. } 184 \text { to permit } \\
\text { calibration of the } \\
\text { regulating rod. }\end{array}$ & $\begin{array}{l}\text { Training lab for the } \\
\text { University of Kentucky } \\
\text { nuclear engineering } \\
\text { students. }\end{array}$ & 12.5 \\
\hline $4-9-76$ & Ionization chamber tests & Test facility for ORMAC & 6.0 \\
\hline $\begin{array}{l}6-28-76 \\
\text { and } \\
6-29-76\end{array}$ & $\begin{array}{l}\text { Established cores Nos. } 185 \\
\text { and } 186 \text { to obtain a } \\
\text { critical mass following } \\
\text { the standard approach- } \\
\text { to-critical procedure. }\end{array}$ & $\begin{array}{l}\text { Training lab for the } \\
\text { Memphis State Universit } \\
\text { students. }\end{array}$ & $\begin{array}{l}23.0 \\
y\end{array}$ \\
\hline
\end{tabular}


Tajle 13. PCA Maintenance

\begin{tabular}{|c|c|c|c|}
\hline Date & Component & Trouble or Change. & Eeas on or. Maintenance \\
\hline $\begin{array}{l}5-3-7.6 \\
\text { through } \\
5-5=76\end{array}$ & $\begin{array}{l}\text { Quar:erly } \\
\text { instrumentation } \\
\text { chəcks }\end{array}$ & Routine & Completed with satisfactory results. \\
\hline $5-3-76$ & $\begin{array}{l}\text { Nc. } 1 \text { magnet } \\
\text { amplifier }\end{array}$ & Unsteady output. & Replaced two OA2 VR tubes. \\
\hline $5-3=76$ & $\begin{array}{l}\text { Auxiliary counging } \\
\text { rate channel. }\end{array}$ & $\begin{array}{l}\text { Did not meet specifica- } \\
\text { =ions. }\end{array}$ & Replacel the pulse amplifier. \\
\hline
\end{tabular}




\section{EXPERIMENTS}

Experiments were conducted at the PCA by students from the Nuclear Engineering Departments of Mississippi State University, the Untversity of Kentucky and Memphis State University as indicated in Table 12. These experiments are described briefly and were directly supervised by the training supervisor of the Operations Division.

\section{Approach-to-Critical}

To demonstrate the technique of assembling a reactor core, a critical mass was loaded by the nuclear englneering students following the standard approach-to-critical procedure:

\section{Regulating-Rod Calibration}

A technique used in calibrating reactor control rods was demonstrated by using the period method in calibrating the regulating rod. The exercise was performed by the nuclear engineering students.

\section{Statistical Weight.}

An experiment was performed to determine the effect of absorbers on the reactivity as a function of position in a special fuel element located in the reactor core. Using guidelines provided by the Operations super-: visor, the experiment was performed by the nuclear engtneering students. 
APPENDIX A

\section{INTRA-LABORATORY CORRESPONDENCE \\ OAK RIDGE NATIONAL LABORATORY}

June 24, 1976

TO:

F. T. Binford

HKÜ: $\quad$ T. P. Hamrisk

SUBJECT: Callbration of BSR Shim Rods

The BSR shim rods were calibrated [ullowing the refue]ling operation to establish BSR loading No. 31. The resulting reactivity worth curves are attached, along with a plul of exceso banctivity remaining versus the ganged rod position of ruls 1-4. Loading No. 31 resulted in a core with $5.49 \% \Delta \mathrm{k} / \mathrm{k}$ excess reactivity at a water temperature of $80^{\circ} \mathrm{F}$.

As determined from this most recent callbration of the shim rods, the minimum position of the shim rods at critical are:

1. All six rods ganged at 10.70 inches withdrawn; and

2. Rods 5 and 6 at 23 inches withdrawn, rods 1-4 ganged at 9.0 inches withdrawn.

Rod worths determined during the five most recent calibrations are compared in Table 1 below:

Tablp 1. Comparison of BSR Rods Worths (\% $\Delta \mathrm{k} / \mathrm{k})$

\begin{tabular}{crrrrr}
\hline Rod No. & $\begin{array}{l}\text { Oct. } \\
1971\end{array}$ & $\begin{array}{l}\text { Jan } \\
1972\end{array}$ & $\begin{array}{l}\text { Sept. } \\
1974\end{array}$ & $\begin{array}{l}\text { June } \\
1975\end{array}$ & $\begin{array}{c}\text { June } \\
1976\end{array}$ \\
\cline { 2 - 6 } & 1.710 & 1.944 & 1.697 & 1.934 & 1.755 \\
2 & 1.690 & 1.864 & 1.873 & 1.259 & 1.843 \\
3 & 2.716 & 3.018 & 2.942 & 3.086 & 2.512 \\
4 & 2.714 & 2.962 & 2.966 & 2.931 & 2.854 \\
5 & 0.922 & 0.852 & 0.946 & 0.940 & 0.854 \\
6 & 0.866 & 0.872 & 0.937 & 0.910 & 1.159 \\
$1-4$ & 8.830 & 9.788 & 9.478 & 9.710 & 8.964 \\
$5-6$ & 1.788 & 1.724 & 1.883 & 1.850 & 2.013 \\
Total & 10.618 & 11.512 & 11.361 & 11.560 & 10.977 \\
\hline
\end{tabular}

T. ̈̈. Hamrick

TPH: dsp

At tachments

E. D. Lance

cc: C. D. Cagle

C. S. Sance

C. B. Gaither

S. S. Hurt

J. R. Thomas

BSR Control Room 


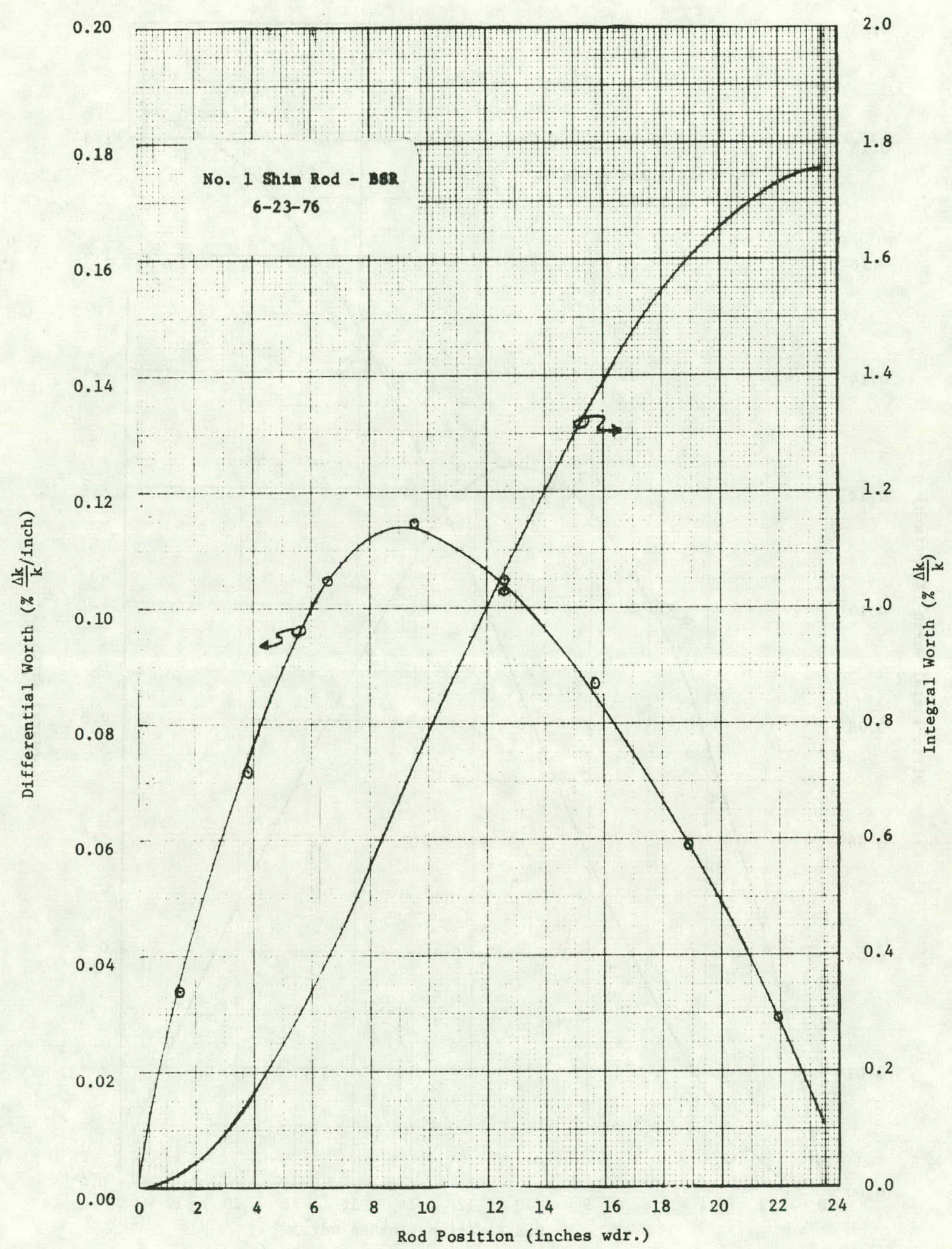




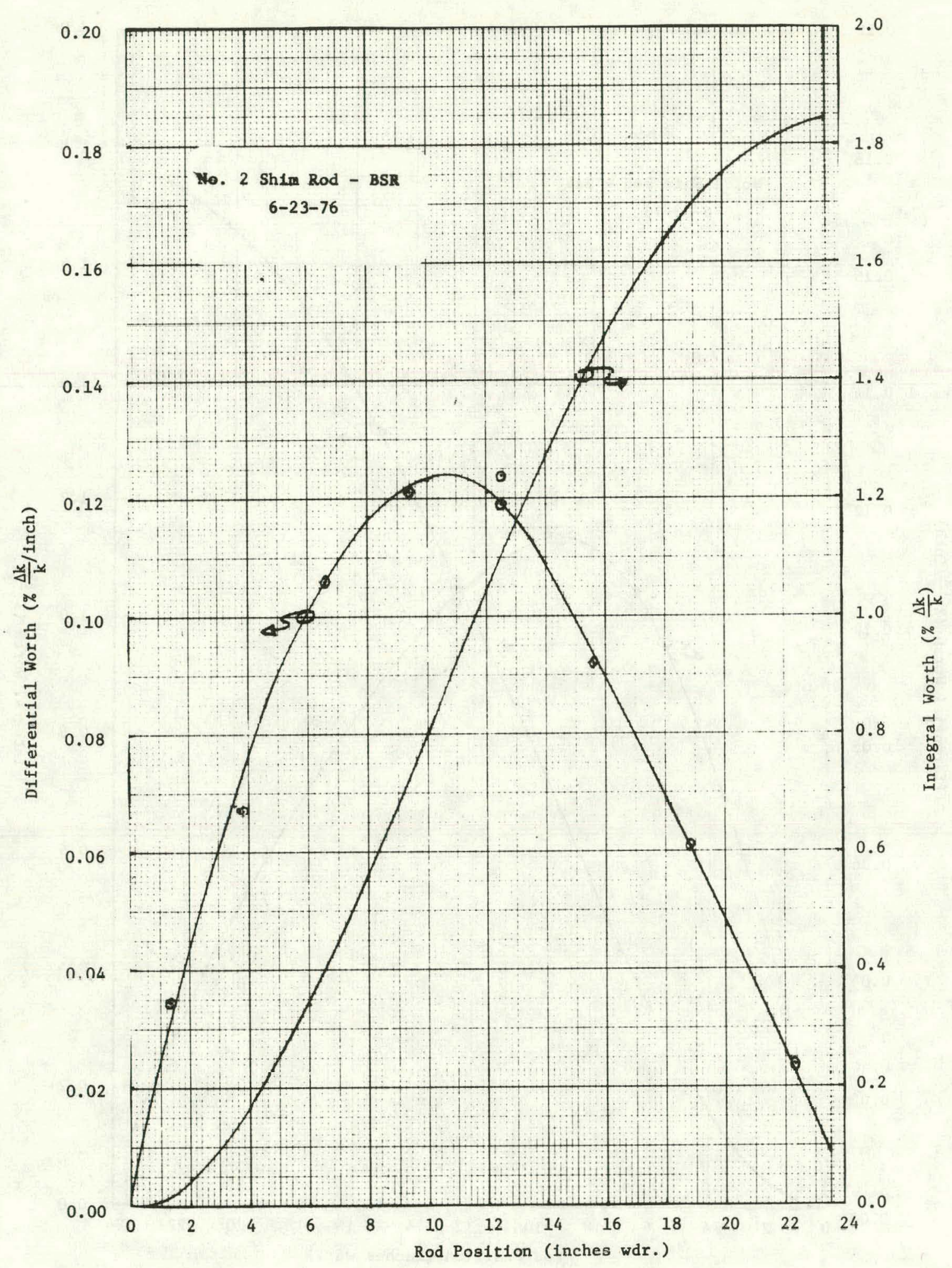




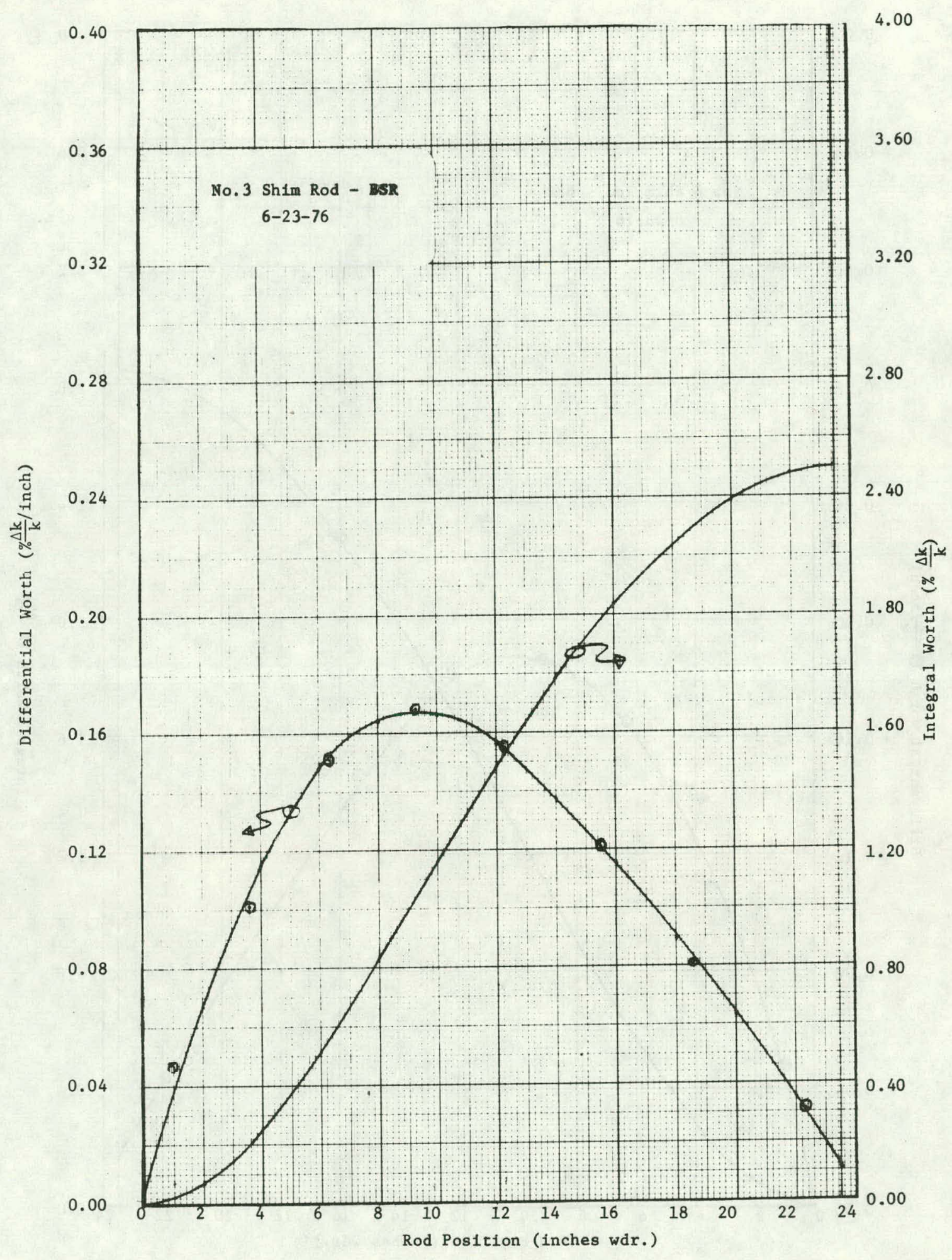




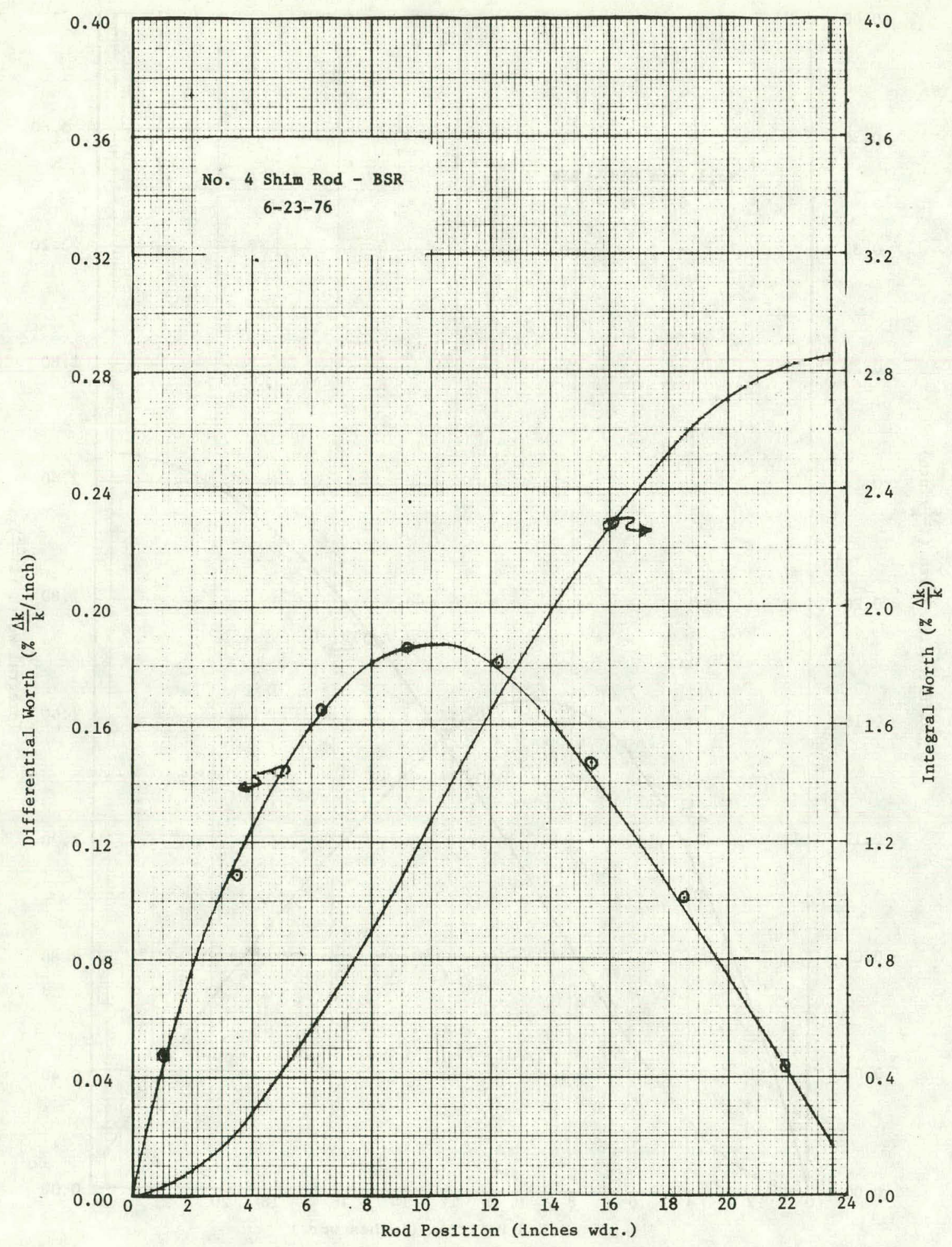




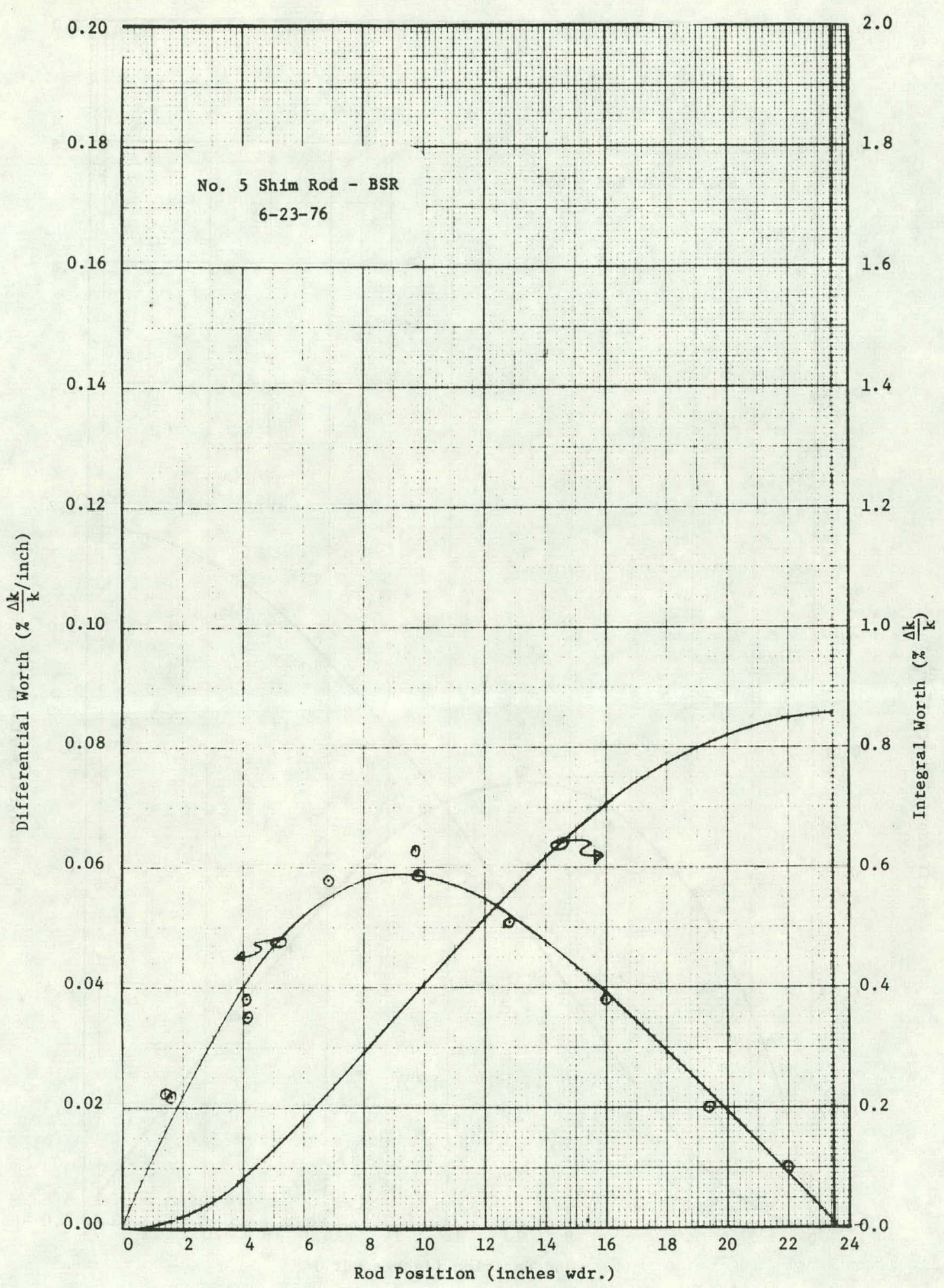




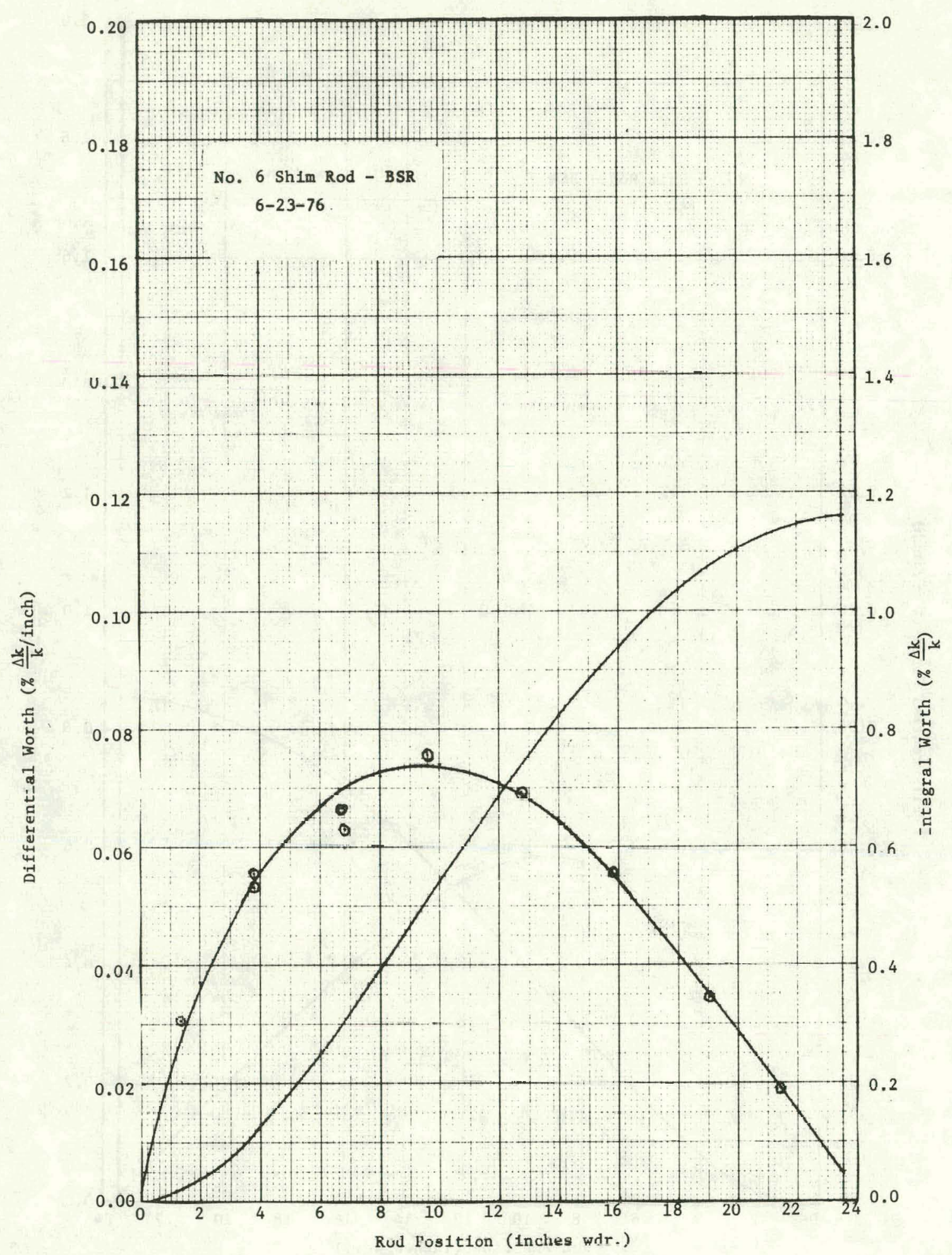




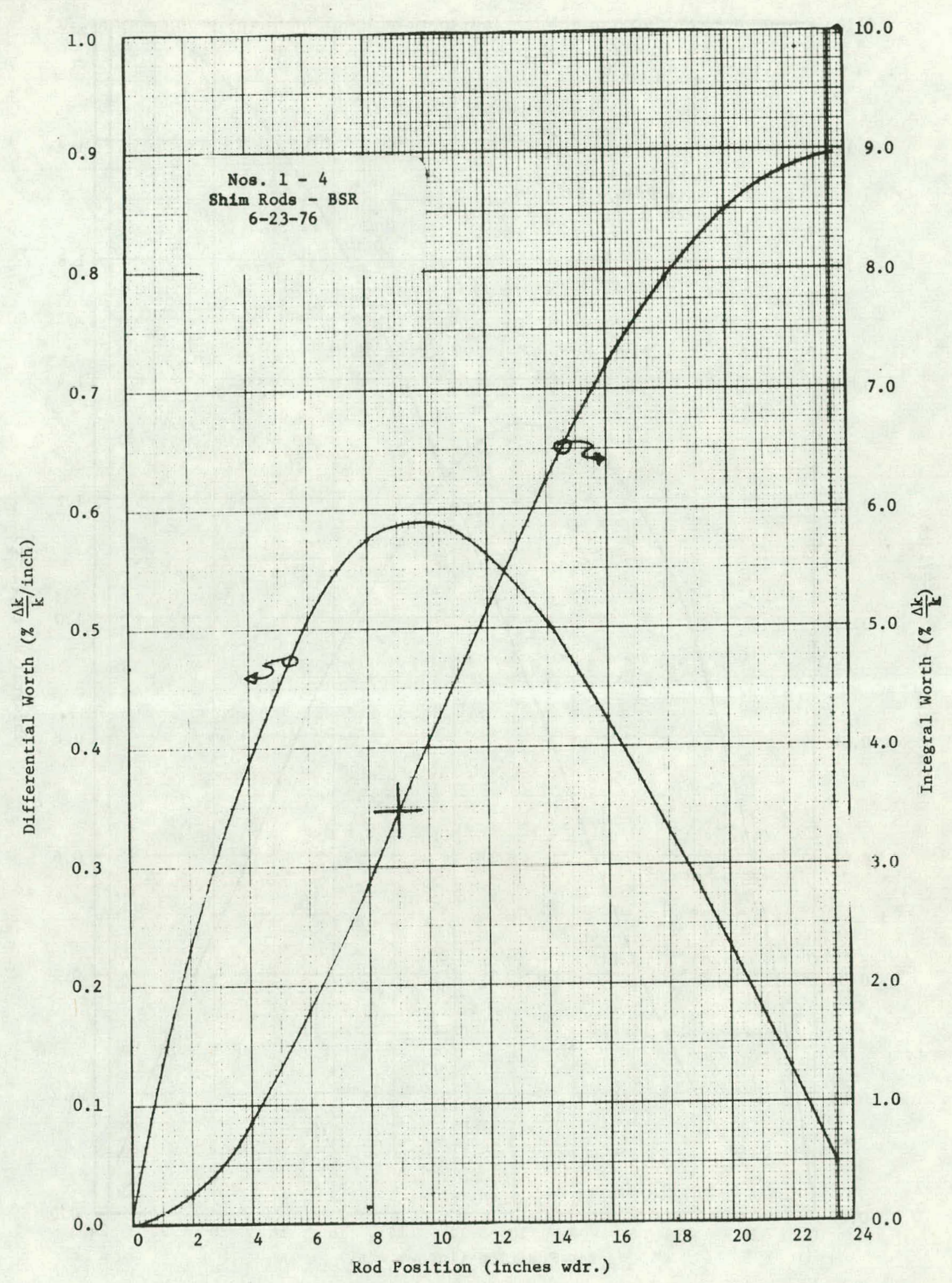




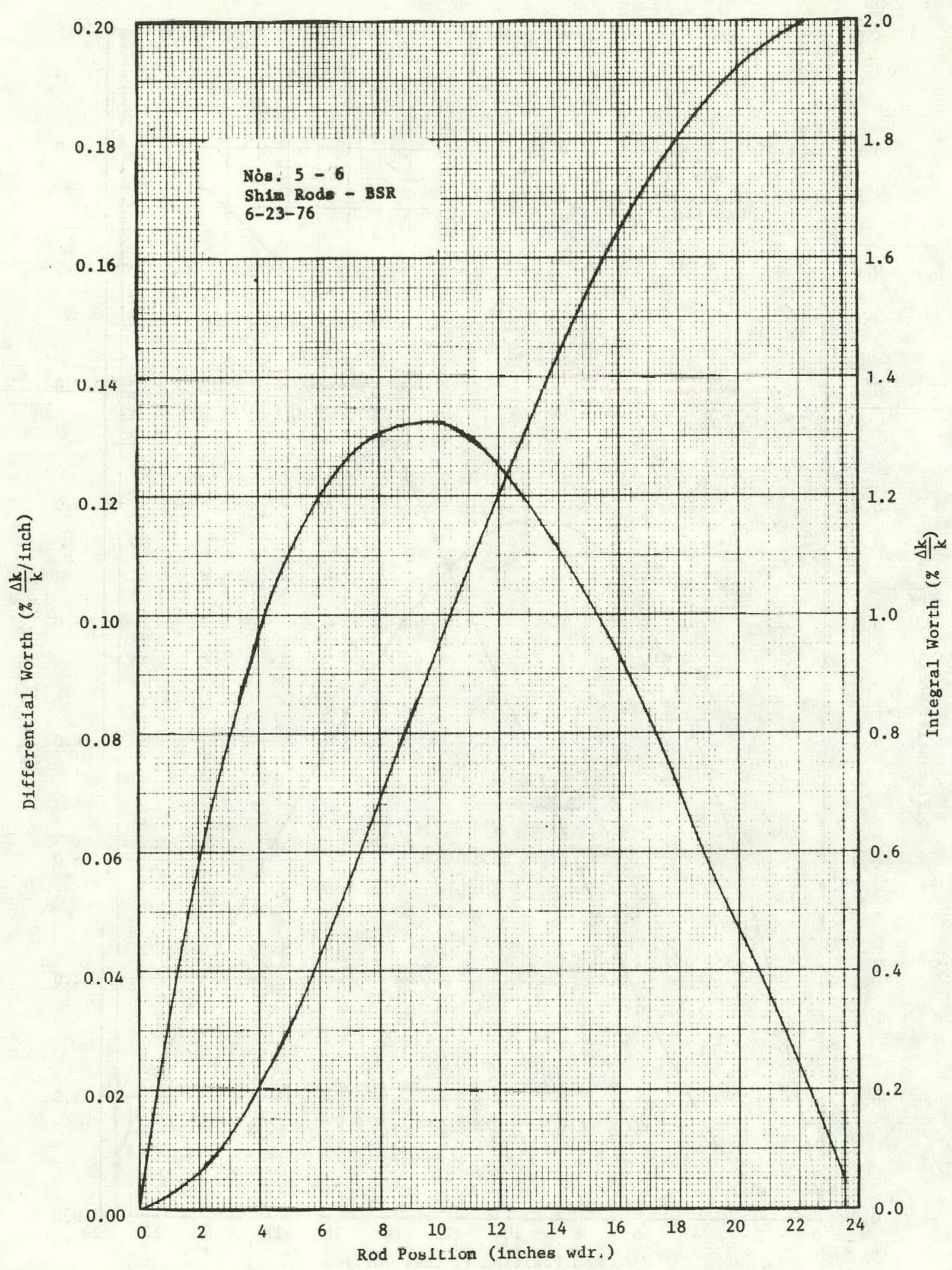




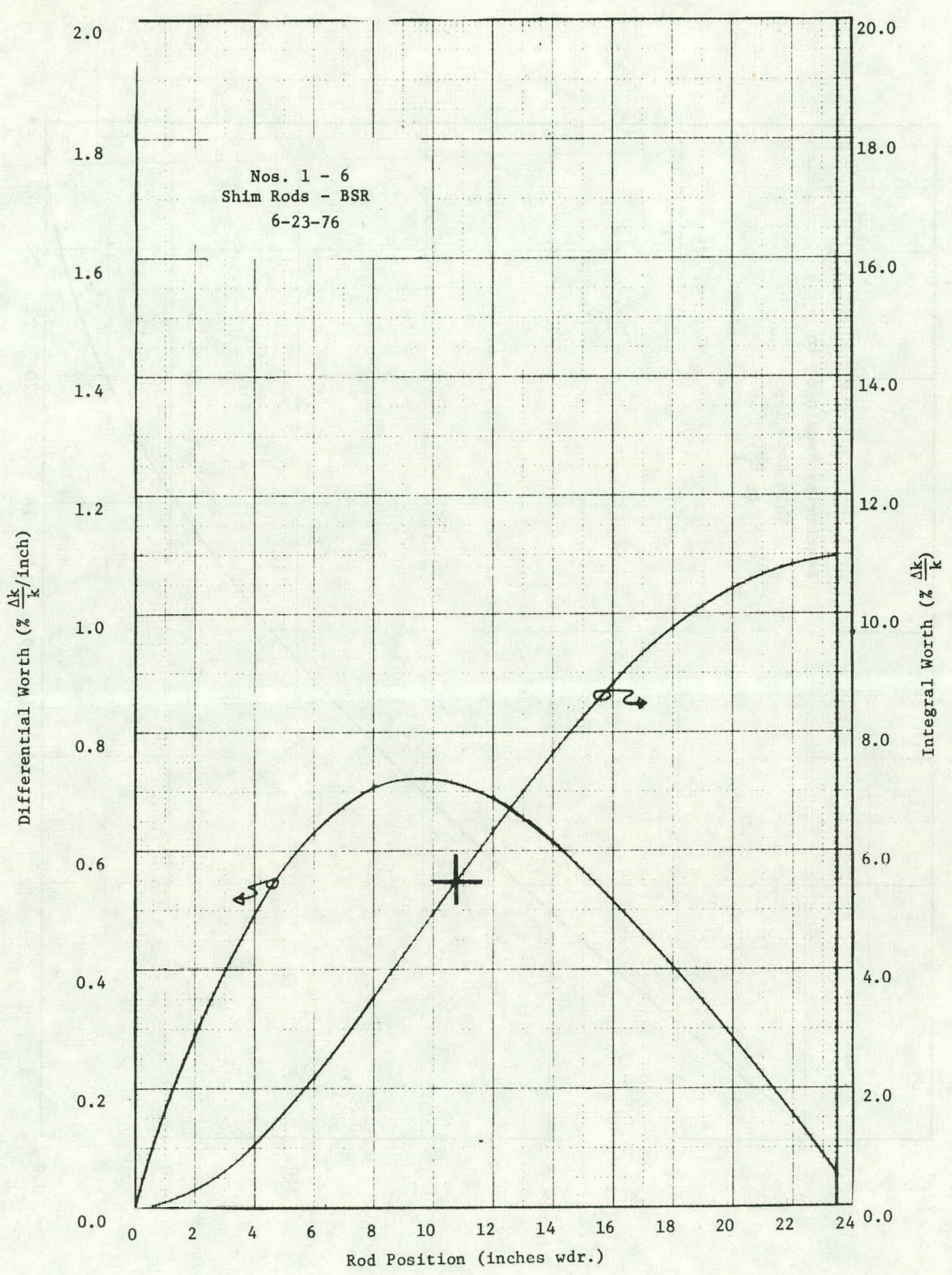




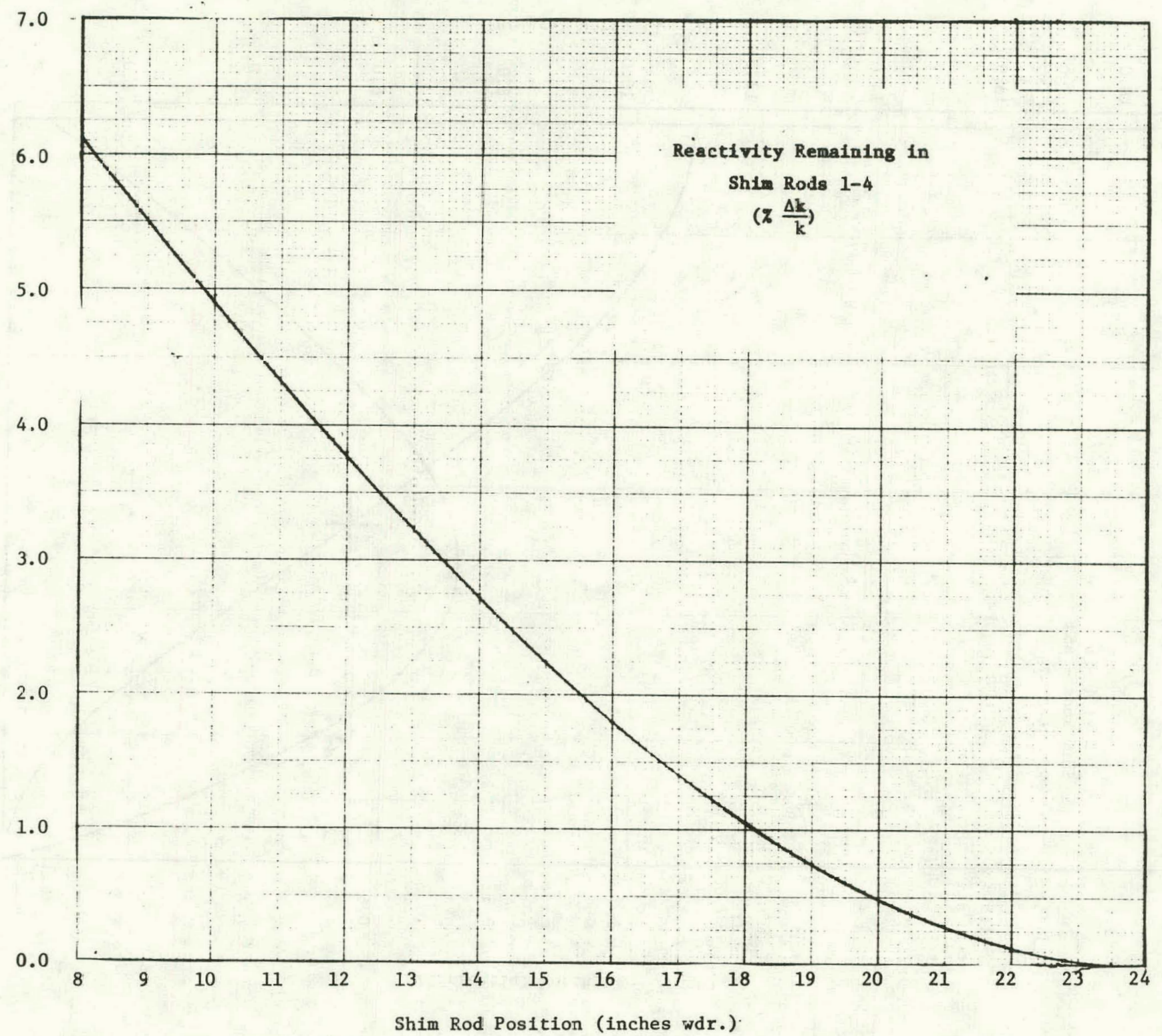


INTERNAL: DISTRIBUTION

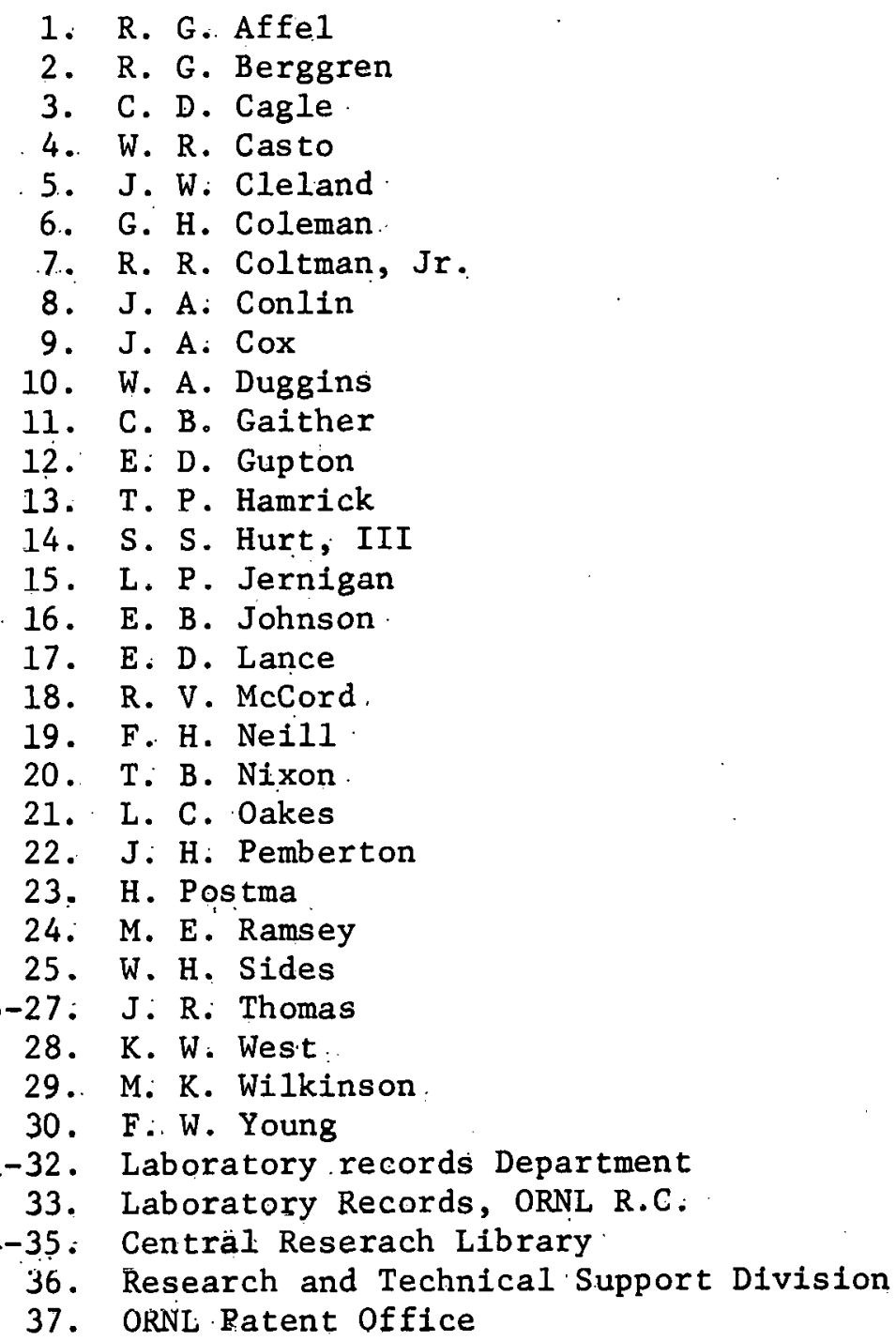

EXTERNAL DISTRIBUTION

38. K. M. Akhtar, Pakistan

39. R. D. Martin, University of Michigan

40. J. D. Randa11, Texas A\&M University

41. D. Segal, Israel

42-43. E. S. Beckjold, ERDA, Washington, D. C :

44. Safety and Environmental Control Division

45-71. Technical, Information Center, Oak Ridge 